\title{
Reform of the budget of the European Union as a process of strengthening the European identity. Are Europeans ready for it?
}

\section{Introduction}

The condition of the European Union's finances has for long been the subject of a lively public debate. The debate focuses around a few elements of which the most important one seems to be the situation in the Euro zone, particularly in Greece which is commonly regarded as the cradle of European civilisation. ${ }^{1}$ The financial problems of Greece illustrate the best the consequences of the lack of due care in the sphere of handling financial matters that have in recent years been observed at the European Union level as well as in individual EU Member States. In particular, the lack of due care (negligence) has manifested itself in the lax financial discipline, and the failure to exercise the fiscal criteria of convergence with regard to such measures as deficit and the general government sector debt. As a result, Member States such as Greece were forced to carry out a reform of the public finance sector which resulted (inter alia) in the implementation of a budget saving plan, the raising of the retirement age, or reduced spending on social welfare programmes. $^{2}$ This therapy turned out to be a real shock for the rich

${ }^{1}$ On the idea of Europe see D. Chalmers, G. Davies, G. Monti, European Union Law, Cambridge 2014, p. 4-11.

${ }^{2}$ On the earthquake of the European sovereign debt crisis see ibidem p. 714-724. 
European nations (societies) that have grown used to a welfare state. Changes, however, are unavoidable, enforced by the changing international environment and global competition. Thus it is so important to understand the mechanisms of these processes and the new priorities that must be satisfied. The latter certainly include innovation, mobility and knowledge upon which the functioning of the economy should be based. ${ }^{3}$ It must also be remembered that the purpose of economic initiatives may not merely be reduced to the multiplication of money, but should first and foremost be aimed at increasing welfare and its proper distribution among members of the society. The contemporary science of finances does not only identify these goals with functions such as fiscal, redistributive or allocative, but places a focus on the social element as well. And yet, a question arises of how these functions are to be fulfilled in the current conditions of economic crisis and omnipresent cuts in the Member States' budgets. The answer is simple. It can be achieved, largely, by a rational, long-term and common as well as properly financed action, carried out throughout the European Union, based on the EU's general budget and the Multiannual Financial Framework (which will be discussed later in this text). It is generally believed that the latter two constitute the main financial instruments which the EU can use to meet the challenges of today. The reform of the European Union follows the enforcement in 2009 of the Treaty on the Functioning of the European Union (TFEU) and covers, among other things, a wide scope of financial matters including those related to the budget. ${ }^{4}$ They address both general issues and principles of the budget policy as well as rules and provisions on the combating financial abuse. These changes in regulations have been accompanied in recent years by a discussion on the reform of the budget itself, and more precisely, the sources of financing its expenses. In spite of the fact that the discussion focuses on the analysis of the different types of financing the EU budget, it frequently contains certain axiological aspects as well. Due to the specific nature of the EU budget and the tasks before

${ }^{3}$ The above goals are being currently pursued by the European Union under the "Europe 2020" strategy whose three main priorities for the coming years are: smart, sustainable and inclusive economy which are to be achieved through activities within the scope of employment, innovation, education, social inclusion and climate/Energy. See Europe 2020, http://ec.europa.eu/europe2020/index_en.htm (accessed: 27 VII 2015).

${ }^{4}$ See Ch.B. Blankkart, G.B. Koester, The Lisbon Treaty, the Financial Crisis and Exit from Budget Gridlock, in: European Union Budget Reform. Institutions, Policy and Economic Crisis, ed. by G. Benedetto, S. Milio, London 2012, p. 79-99. 
it, the non-financial (evaluating) elements are extremely important. An analysis of the discussion on the reform of the EU budget raises a question concerning the possibility of including among its objectives the idea of a federal Europe, based on common values. ${ }^{5}$ Another equally important issue is a possibility of obtaining increased funds sourced in the EU budget that could be spent on the implementation of these values. Is this at all possible? Or is it necessary to seek new financing sources which would secure independence of EU finances of its Member States? Are societies of individual Member States ready to accept such solution? Is not the current system sufficient for the purpose? Where does the need for a change originate, or are changes realistic or feasible? Will they strengthen the feeling of European identity among the inhabitants of the United Europe? Attempts to answer these and many other questions asked in connection with the promised reform of the EU budget will be made on the next pages of this paper, in which we aim to justify a thesis that despite the occasional lack of understanding of the necessity of financing certain initiatives from the EU budget, this process is effective and contributes to the implementation of the idea of United Europe. It requires, however, certain changes that need to be made in order to make the EU budget even more independent of the will of Member States, ensuring at the same time that benefits available from the European Union funds are justly and fairly redistributed among all Member States. These benefits should be understood broadly and include those visible ones (e.g. infrastructure) and those invisible, soft benefits seen as universally appreciated intellectual capital, as well as the implementation of such values as solidarity or subsidiarity upon which the European Union is founded. ${ }^{6}$

\section{Budget of the European Union - basic remarks}

The discussion on the draft reform of the EU general budget ought to start with a brief description of its nature, its underlying principles and functions. An element that has been inseparably tied to the EU budget since 1988 is its financial prospects. Since 2009 and the enforcement of the amended Treaty, financial prospects of the EU have been referred

${ }^{5}$ See V. Reding, Why We Need a United States of Europe Now, Centrum für Europarecht an der University Passau, 8 November 2012, Speech/12/796.

${ }^{6}$ M.N. Jovanović, The Economics of European Integration, Cheltenham 2013, p. 179. 
to as the Multiannual Financial Framework (MFF). ${ }^{7}$ The origin of these two institutions does not have to be analysed in detail in this work, it will suffice to say that the beginning of the budget reaches as far back as the inception of the Communities. ${ }^{8}$ Originally the budget served to finance only limited initiatives undertaken at the European level. Later, together with increased activity of Brussels and new actions undertaken by EU bodies, budget expenditures had gone up, which entailed the necessity to increase its revenues. ${ }^{9}$

The EU legislation does not, as yet, contain a clear-cut and unambiguous definition of the "budget", or its legal form. ${ }^{10}$ However, Art. 310 (1) TFEU provides that the budget should be balanced both with regard revenues as well as expenditures. Thus this article should be regarded as a legal act adopted according to a certain procedure, providing for a statement of revenues and expenditures. The latter are realised based on certain legal principles and serve to achieve the tasks vested in the European Union. This is certainly not a typical state budget, and its characteristics is obviously a consequence of the specificity of the European Union and its goals. It is a specific fund of redistributive and supranational character. The redistributive feature means that its revenues are supplied by Member States and subsequently allocated to complete certain tasks. The supranational character of the EU budget is ensured by the fact that it is planned, adopted and implemented by bodies vested with formal, organisational and financial autonomy, independent of the Member States which constitute the source of the budget funds. ${ }^{11}$

This autonomy is not complete, though, as it depends on the will of the states that are the first recipients of certain funds, of which a part

${ }^{7}$ G. Benedetto, Budget Reform and the Lisbon Treaty, in: European Union Budget Reform. Institutions, Policy and Economic Crisis, ed. by G. Benedetto, S. Milio, London 2012, p. 44-47.

${ }^{8}$ European Union Public Finance, Brussels 2008, p. 13-23.

${ }^{9}$ See R. Baldwin, Ch. Wyplosz, The Economics of European Integration, Berkshire 2012, p. 79-85.

${ }^{10}$ It is not adopted in the form of a decision, regulation or directive, or any other source of European law. An opinion that may be met in EU publications proposes that it has a form of an authorising act, i.e. a legal basis recommended by the European Commission and endorsed by a legislative body. See The European Union budget at glance, http://ec.europa.eu/budget/library/biblio/publications/glance/budget_glance_en.pdf, p. 8 (accessed: 27 VII 2015).

${ }^{11}$ M. Cieślukowski, Budżet Unii Europejskiej - kierunki reformy, in: Finanse i bankowość w integrujacej się Unii Europejskiej, ed. by T. Famulska, J. Nowakowski, Warszawa 2006, p. $175-176$. 
is subsequently, through those states, transferred to the EU budget. What is more, it is the Member States and not the EU bodies who have a final deciding voice with regard the source of budget revenues. This is because the functioning of the EU budget is based on so-called own resources as referred to in Art. 311 TFEU, which provides for two important legal bases of the EU budget.

One relates to the own resources created in the course of a highly formalised procedure, and which depend on the will of Member States. Its aim is adoption of a unanimous decision regarding the applicable catalogue of own resources, manifested as individual categories of the European Union budget revenues. In practice, this means a long and laborious process of adopting this legal act which has a retroactive force as of the day of its adoption. As an example here, can serve the current legal basis for today's catalogue of own resources, i.e. the Council Decision of 7 June 2007 on the system of own resources of the European Communities. ${ }^{12}$ Although it was repealed by Council Decision No 2014/335 of 26 May 2014 on the system of own resources of the European Union ${ }^{13}$, that decision, as provided for in Art. 11, was to come into force and start binding as of 1 January 2014, pursuant to the wording that "this decision shall enter into force on the first day of the month following receipt of the last of the notifications of the Member State. Member States shall notify the Secretary-General of the Council without delay of the completion of the procedures for the adoption of this Decision in accordance with their respective constitutional requirements". Besides the complicated procedure of its adoption, it is also worth noting that it will not be adopted if there is no unanimity of all Member States. And so, should it come to a possible reform of the EU budget, and of the sources of its financing in particular, a unanimous decision of all Member States of the European Union will be required. Currently, pursuant to Art. 2 of Decision 2014/335, the following categories of own resources can be distinguished:

1. traditional own resources (TOR) consisting of levies, premiums, additional or compensatory amounts, additional amounts or factors, Common Customs Tariff duties and other duties - around $12 \%$ of the revenues,

${ }^{12}$ Council Decision of 7 June 2007 on the system of the European Communities' own resources (2007/436/EC, Euratom), O.J. (L 163) 17.

${ }^{13}$ Council decision of 26 May 2014 on the system of own resources of the European Union (2014/335/EU, Euratom), O.J. (L 168) 105. 
2. own resources based on value added tax (VAT) - around $13 \%$ of the revenues,

3. own resources based on Gross National Income (each Member State transfers a standard percentage of its GNI to the EU. This system has become the largest source of revenue of the EU budget (around 74\% of the revenues) and is the most efficient. The level of those contributions is established at the end of each budget formation as the last one, once all other sources (TOR and VAT) have been estimated, and it is meant to constitute a complementary amount, necessary to balance out the budget. The latter is very important since one of the fundamental governing principles of the whole budgeting process is a prohibition of a planned deficit in the general budget of the European Union. What it means in practice is that if it were not for that source, based on the "good will of Member States" the functioning of the European Union would be impossible.

Another element of budgetary revenues are other sources of revenue (around 1\%) that include tax and other deductions from EU staff remunerations, or bank interest. They are not, however, counted among own resources.

The above revenues are used to cover budgetary expenditure divided into the following categories: ${ }^{14}$

1. smart and inclusive growth (around $44.9 \%$ of expenditures), within which there is a distinction between: economic, social and territorial cohesion as well as competiveness for growth and jobs,

2. special instruments $(0.4 \%)$,

3. administration $(5.9 \%)$,

4. global Europe (5.8\%),

5. security and citizenship (1.5\%)

6. sustainable growth: natural resources (41.6\%).

The above expenditures refer closely to the priorities (headings) included in the Multiannual Financial Framework, and referred to in Art. 312 TFEU, pursuant to which "the multiannual financial framework shall ensure that Union expenditure develops in an orderly manner and within the limits of its own resources. It shall be established for a period of at least five years and the annual budget of the Union shall comply with the multiannual financial framework. The Council, acting

${ }^{14}$ Data applicable to 2014. See 2014 EU budget at a glance, European Union, Luxembourg 2014, p. 4. 
in accordance with a special legislative procedure, shall adopt a regulation laying down the multiannual financial framework. The Council shall act unanimously after obtaining the consent of the European Parliament, which shall be given by a majority of its component members". These days, annual Union budgets are being developed in correlation with the MFF for the 2014-2020 period, and are based on Council Regulation No 1311/2013 of 2 December 2013 laying down the multiannual financial framework for the years 2014-2020.15

The concept of multiannual financial frameworks, previously called financial prospects, dates back to the eighties of the 20th century when considerable tensions arose when it came to the balancing out of the Union budget, being a consequence, among other things, of the new circumstances in which the European integration process was going on, namely the inclusion of new members (Spain and Portugal) and adoption of the Single European Act, aimed at creating conditions for the actual implementation of the idea of a single internal market. ${ }^{16}$ These changes implied certain costs and enforced implementation of some financial reforms which commenced in 1988. At a summit on 24 June 1988, the European Council decided that the European Communities needed to have at their disposal adequate financial resources enabling them to act in an effective, stable and predictable manner throughout the years 1988-1992. This was followed by the adoption of two important acts: (i) the Council Decision 88/376/EEC of 24 June 1988 on the system of the Communities own resources ${ }^{17}$ and the Council Decision $88 / 377 /$ EEC on budgetary discipline. ${ }^{18}$ As is commonly believed ${ }^{19}$, the effectiveness of the reforms was also highly influenced by the Inter-institutional Agreement on budgetary discipline and improvement of the budgetary procedure. ${ }^{20}$ Further, it was also decided to implement the idea of long-term planning, which materialised as the first financial prospect for the years 1988-1992 (Delors I).

${ }^{15}$ Council regulation (EU, Euratom) no. 1311/2013 of 2 December 2013 laying down the multiannual financial framework for the years 2014-2020, O.J. (L 347) 884.

${ }^{16}$ K. Żukrowska, Budżet ogólny Unii Europejskiej, Warszawa 2009, p. 55.

${ }^{17}$ Council Decision of 24 June 1988 on the system of the Communities own resources (88/376/EEC, Euratom), O.J. (L 185) 24.

${ }^{18}$ Council Decision of 24 June 1988 concerning budgetary discipline (88/377/EEC) O.J. (L 185) 29.

${ }^{19}$ K. Żukrowska, op. cit., p. 60.

${ }^{20}$ O.J. (L 185) 33. 
This kind of planning was intended, on the one hand, to ensure better control of the expenditures from the general budget of the European Union over a longer period of time, and on the other hand, to streamline the budgetary funds with the aim of achieving certain priorities. These measures were undertaken in the context of the "managed market economy" which characterised that period and which was identified with so called Washington consensus. ${ }^{21}$ As K. Żukrowska proposed, two aspects of this type of management are particularly noteworthy: $:^{22}$

- the existence of a general budget mechanism through which redistribution of funds from countries of more highly developed economies to poorer countries is made, and

- the existence of possibilities of using financial resources focused on mid-term and long-term goals.

This philosophy is still observed in today's budgetary policy of the European Union, which continues to evolve as it has since its very inception. It is based on two pillars: the general budget of the European Union and the multiannual financial frameworks.

A question should be asked here about the nature of the Union budget. Can it, despite the fact that it is not a typical state budget, be compared to the budget of a federal state? Certainly not, although there are voices expressing an opinion that it is in a way similar to the federal budget ${ }^{23}$ and the principles of the theory of fiscal federalism may therefore be applied to it ${ }^{24}$, particularly those which define this theory through a possibility of delegating competences regarding fiscal policy from the central level to lower level of the functioning of a state, resulting in better effectiveness of allocated funds and their redistribution. ${ }^{25}$ In

${ }^{21}$ This concept is understood as actions carried out in order to limit the costs that do not have any influence on the growth of budget dynamics, and which allow to assign the saved funds to pro-development activity that stimulates growth (innovations, scientific research and the like)

${ }^{22}$ K. Żukrowska, op. cit., s. 63.

${ }^{23}$ J. Pietras, Przyszłość budżetu Unii Europejskiej. Spójność celów, polityk i finansów unijnych, Warszawa 2008, p. 17.

${ }^{24}$ M. Cieślukowski, Dotacje Unii Europejskiej w świetle teorii federalizmu fiskalnego, "Zeszyty Naukowe Uniwersytetu Szczecińskiego" 2009, no. 546, p. 38 et seq.; different: K. Stabryła, Przyszłość budżetu ogólnego Unii Europejskiej w obliczu nowych wyzwań integracyjnych, "Zeszyty Naukowe Uniwersytetu Szczecińskiego" 2009, no. 546, p. 367.

${ }^{25}$ On fiscal federalism see: R. Baldwin, Ch. Wyplosz, op. cit., p. 473-475; M.N. Jovanović, op. cit., p. 376-378; K. Piotrowska-Marczak, Podstawy teoretyczne i koncepcje federalizmu fiskalnego, in: Federalizm fiskalny w teorii i praktyce, ed. by K. Piotrowska-Marczak, Warszawa 2009, p. 9-40. 
this theory, the influence of the principle of s u b s i d i a rity, which apart from the principle of proportionality and solidar$i t y$ is the most important principle when it comes to the functioning of the EU budget as well as the European Union itself. The principle of subsidiarity provides that the funds from the Union budget should be used to finance projects the completion of which at the supranational level will be will bring more benefits than when expenditures (and revenues) are realised at an individual Member State level. ${ }^{26}$ What is more, funds that richer EU Member States transfer via the EU budget to less well-off Members as a manifestation of solidarity, are intended to help to latter to catch up with the development level and well-being and prosperity of their citizens. This 'additionally' consists in treating the funds from the Union budget as additional financing sources which, in conjunction with national sources enable realisation of goals otherwise impossible to realise. ${ }^{27}$ These funds should, according to the principle of proportionality, be attracted as well as spent in an adequate manner, contributing, in the long-term, to the creation of European Added Value.

The concept of European Added Value ${ }^{28}$ should be associated with benefits arising from the implementation (realisation) of the Union budget expenditures that have earlier been determined for a long-term period and endorsed as MFFs. In most cases they are 7-year plans as, for example, the current 2014-2020 framework. Thus they constitute financial frameworks which, on the one hand allow long-term financial planning, and on the other hand discipline budgetary spending in a given financial year. The essential element of the MFFs is, apart from determining the amounts intended to be spent in a several-year peri$\mathrm{od}^{29}$, predominantly, the priorities (headings) to which those funds are assigned, and whose realisation serves to maintain the potential and economic growth of United Europe. ${ }^{30}$

${ }^{26}$ M. Cieślukowski, Budżet Unii Europejskiej..., p. 175-179.

${ }^{27}$ K. Stabryła, op. cit., p. 369.

${ }^{28}$ D. Tarschys, The Enigma of European Added Value: Setting Priorities for the European Union, SIEPS Report 2005, no. 4, p. 38-80.

${ }^{29}$ While reforming the Treaty it was taken that the existing 7-year period in which the subsequent financial prospects were made was too long and therefore disabling the adjustment of priorities to the rapidly changing external conditions being a consequence of globalisation. Thus a decision to introduce into the TFEU the provision of Art. 312 which provides that the financial framework is to be determined for a period of at least 5 years.

${ }^{30}$ L. Oreziak, Perspektywa Finansowa 2007-2013 - kierunki ewolucji systemu finansowania Unii Europejskiej, “Bank i Kredyt” 2004, no. 7, p. 4-14. 
It must be emphasised here that economic growth is one of the elements of the aforementioned added value. Numerous publications on the Union budget point out to the difficulty of determining that value and how it should be estimated. ${ }^{31}$ It is tied to the principle of subsidiarity because moving of the financing of certain expenditures from the national level to the supranational, i.e. the European Union, level, allows to achieve benefits which would not have been possible to achieve in a situation in which individual Member States were to undertake certain (individual) activities. Thus, in this way, a synergy effect can be achieved. However, and this is stressed by J. Pietras, the problem with the Union budget is that till now no adequate instruments have been developed, to allow to estimate the benefits that do flow from the Union budget, and which are reflected in the above mentioned added value. ${ }^{32}$ An interesting solution of this problem could be achieved by defining the benefits arising from the use of a budgetary expenditure as a situation which creates or constitutes a credible prospect of a return that would be to the benefit to at least two Member States. ${ }^{33}$ As an example of such situation, European Union documents create, among other things, expenditures on infrastructural projects, including trans-European networks. These, partially financed from the EU budget, serve a group of countries and indirectly the whole united Europe. Such perception of benefits that extend on a wider than only national scale has been, in fact, recently promoted in the literature devoted to public finances. A new approach to public spending has been recommended by P. Jones, as an attempt to create a global public good. ${ }^{34}$ And indeed, internationalisation of global economy creates a new quality of social life, functioning in the fourth dimension of social space, and taking the form of global context independent of place, distance or borders. ${ }^{35}$ Thus, funds used for such purposes, as for instance the funds from the EU budget, may at the same time serve to realise the traditional budgetary functions, i.e. fiscal, redistributive, allocative, stimulating and that of supervision. And yet, as rightly pointed out by M. Cieślukowski,

${ }^{31}$ D. Tarschys, op. cit., p. 82-95.

${ }^{32}$ J. Pietras, op. cit., p. 24.

${ }^{33}$ D. Tarschys, op. cit., p. 99.

${ }^{34}$ P. Jones, Taking Self-interest into Account. A public Choice Analysis of International Cooperation, in: The New Public Finance: Responding to Global Challenges, ed. by I. Kaul, P. Conceição, New York 2006, p. 304-324.

${ }^{35} \mathrm{~J}$. Gałuszka, Polityka fiskalna wobec procesów globalizacji, in: Wspótczesne finanse, ed. by J. Głuchowski, Toruń 2008, p. 384. 
an analysis of the funds must take into account the exceptionality of the goal which the budget serves. When it comes to the EU budget, for example, it cannot, due to its, inter alia, size and specific character, be treated as a tool for regulating economic prosperity or combating poverty. This is because, firstly, a Union budget may not be adopted if it provides for a deficit (Art. 310.1 TFEU), which, when "appropriately" used constitutes an element of economic policy, and, secondly, because of the absence of an all-over-Europe tax which could, in conjunction with transfer payments such as pensions, influence the social condition of the European Union citizens. ${ }^{36}$

The function of the EU budget deficit is taken over by the above mentioned multiannual framework financing arising from certain strategies such as e.g. Europa 2020. This strategy should be currently regarded as the fundamental programme document upon which the financial reforms are to be based, both at the supranational as well as the national level, for the implementation of which financial support from the European Union budget is essential. This thesis has been in fact confirmed in the communication of the Commission to the European Parliament, the European Economic and Social Committee and the Committee of the Regions of 29 June 2011 "A budget for Europe 2010" in which individual Union expenditures planned for the coming years have been determined and described. ${ }^{37}$

The goals of the above strategy are being currently pursued in a consistent manner and the reforms implemented with the use of budgetary funds bring about measurable effects, both tangible and intangible. The tangible effects can be observed in new Member States, recently included in the EU structure, in which the infrastructure is undergoing visible changes and in which cultural development or education is being financial supported with the EU funds. There is a problem, though, to convince the payers as well as the beneficiaries that the costs incurred are justified and well spent. Although the former make bigger contributions to the Union budget, they still benefit from it, gaining new markets, or involving their enterprises in various projects conducted with the support of the Union budget funds. The benefits of the latter group are obvious, although they do not always affect directly individual citizens

${ }^{36}$ M. Cieślukowski, Budżet Unii Europejskiej..., p. 180.

${ }^{37}$ Communication from the Commission to the European Parliament, the Council, The European Economic and Social Committee and the Committee of the Regions, A Budget for Europe 2020, COM/2011/0500 final. 
in a matter they may have expected. The financing system with the use of the Union funds certainly serves to implement the ideas underlying its creation. However, due to the crisis suffered by public finances in individual Member States it has been decided that it will be necessary to find a new formula of financing the budget of the European Union and to make the Union budget less dependent on the budgets of the EU Member States.

\section{Reform of the EU budget - why do we need it and how can we do it?}

Work on the reform of the EU budget commenced after the European Parliament, the European Council and the European Commission decided in May 2006 that the latter should initiate a process of budget reforms consisting of an overall and comprehensive review of all expenditures, including those related to agricultural policy, the EU budget's own resources and the UK rebate, in order to present a relevant report on the state of affairs in 2008/2009. ${ }^{38}$ The process of wide consultations ended on 12 November 2008 with a conference on: "Reforming the Budget, Changing Europe".

The document underlying the above consultations was a Communication from the Commission entitled "Reforming the Budget, Changing Europe. A public consultation paper in view of the 2008/2009 budget review 2008-2009"39 which identified issues that required an analysis with regard to: the current role of the budget, the shaping of the future budget with particular focus on the added value of EU's expenditures, and budget financing. These issues constituted the basis upon which many other related issues were also debated, of which two should be mentioned here as especially noteworthy: the then existing structure of own resources and their redefinition, while at the same time ensuring their independence of the budgets of Member States by, for instance, creating new categories of resources to

${ }^{38}$ See Inter-institutional agreement between the European Parliament, the Council and the Commission on budgetary discipline and sound financial management, 2006 (O.J. C 139 01, Declaration 3).

${ }^{39}$ Communication from the Commission - Reforming the budget, changing Europe A public consultation paper in view of the 2008/2009 budget review, SEC/2007/1188 final. 
replace or complement the existing ones. Possible solutions to the above problems included introduction of certain taxes, among them the most frequently mentioned in this context "European" value added tax (VAT), the corporation income tax CIT, or a completely new European $\operatorname{tax}^{40}$, paid by individuals.

Freeing the EU budget from the dependence on Member States budgets was deemed absolutely necessary since, despite various opinions, the EU budget is one of the essential tools of the on-going policy of European integration which, in order to be fully successful, requires not only a political union, but also a homogenous budgetary policy that would eliminate the thinking in "net" categories only. Such net oriented policy points to nothing more but the differences between funds paid into and received from the budget. ${ }^{41}$ This problem has prevailed for years, and has been discussed in light of the logic of so called juste retour - just return. In this logic, the approach to the budget is entirely calculative, which means that amounts paid in are compared with those paid out and what really counts is the final balance for a given state. The "net" only approach takes an extremely subjective view and disallows a full evaluation of the benefits flowing from the EU budget to individual Member States, especially in a situation in which the contributions made to the budget exceed transfers received from it. A classic example of argumentation in the debate is so called Rotterdam effect ${ }^{42}$, which effects states which play the role of merely transit countries for the goods imported to the EU internal market. Countries through which goods from third countries enter the EU market are obliged to collect customs duties which they subsequently transfer to the EU budget. However, as it frequently happens, consumption of the introduced goods and arising from benefits are felt in other Member States, while the customs duty collector e.g. the Netherlands not only fails to fully benefit from the consumption of taxed goods, but also, and not infrequently, is among the biggest EU budget contributions payers, being obliged to finance it in amounts proportional to its wealth. And yet, the thinking of the budget in this approach involves thinking of numbers only, disregarding other benefits flowing from the above mentioned European value

${ }^{40}$ See I. Begg, An EU Tax. Overdue Reform or Federalist Fantasy, Friedrich Ebert Stiftung, International Policy Analysis, 2011, p. 10-15.

${ }^{41}$ K. Stabryła, op. cit., p. 372 et seq.

${ }^{42}$ It must be emphasised that in the case of the Rotterdam effect, focus is predominantly on revenues whereas expenditures are considered as so called Luxemburg effect. 
added. ${ }^{43}$ Hence the need to emphasise all the time the very essence of added value and to multiply examples illustrating the value added, otherwise difficult to measure. Such examples include, for instance the fact that better road infrastructure supports better mobility of European citizens, facilitating familiarisation with other cultures, which in turn helps to overcome cultural prejudices and other barriers, so important for the stabilisation on the continent. Another important argument in the discussion is provided by economic data which prove that the paying states likewise the beneficiaries draw benefits from the fact of the existence and functioning of the budget of the European Union. In 2011 a report was published on "Evaluation of benefits to the EU-15 countries resulting from the implementation of the Cohesion Policy in the Visegrad Group countries". ${ }^{44}$ Its purpose was "to estimate how EU15 economies are affected by the EUR 140 billion (in fixed prices of 2005) spent on the implementation of the Cohesion Policy in the Visegrad Group countries (i.e. Czech Republic, Slovakia, Hungary and Poland). In the opinion of the authors of the report, "an analysis shows that the impulse for development resulting from the Cohesion Policy in the V4 countries translates into a significant increase in their output and hence their consumer, investment and intermediate demand that to a large extent concerns goods and services from EU15 countries. Analysing the shape and scale of the Cohesion Policy (based on data of the European Commission and V4 countries), its macroeconomic effects (based on our estimates using the EUImpactMOD model) and the characteristics of the V4 countries in terms of import-intensity and foreign trade flows,

${ }^{43}$ Certain activities undertaken by European politicians provide support for this kind of rhetoric. And so, the initiative of five European leaders: Nicolas Sarkozy, Angela Merkel, David Cameron, Mark Rutte and Mari Kiviniemi who addressed a letter on 18th December 2011 to the European Commission demanding a freeze in the EU budget in the name of austerity has been broadly commented in the debate on the budget. The wrote "European public spending cannot be exempted from significant effort by the Member States which are aiming to bring their public spending under control". "The implementation of ambitious European policies at the service of its citizens is possible but with a stable amount of spending. It demands a better use of the funds available", they believe. See A letter from Prime Minister David Cameron and other European leaders to the President of the European Commission on 18 December 2010, https://www.gov.uk/ government/news/letter-to-president-of-european-commission (accessed: 4 VIII 2015).

${ }^{44}$ Evaluation of benefits to the EU-15 countries resulting from the implementation of the Cohesion Policy in the Visegrad Group countries. Final report, IBS, Warsaw 2011. See also material available from http://ibs.org.pl/app/uploads/2016/07/IBS_Report_01_2011.pdf (accessed: 4 VI 2016). 
we show that on average 1 net euro spent by EU15 countries (net contributors) on the Cohesion Policy in the V4 countries results in 61 cents of additional exports to the $\mathrm{V} 4{ }^{\prime \prime}{ }^{45}$

This dependence is rarely raised in the debate on the reform of the EU budget. This is probably because currently its basic financial source are contributions from Member States' budgets, the size of contribution being tied to their GNIs. Although both are counted as own resources, a more detailed analysis leads to a conclusion that the term "own" is illusory, since ensuring this category of budget sources would not be possible without express will of all Member States which, when making contributions, must follow their own political procedures and those are, in turn, shaped by the political situation in an individual Member State (and in consequence social support for substantial transfers to the Union budget) and its economic prosperity. This applies in particular to the budget contributors (net payers), or in other words those states whose direct transfers to the budget exceed the amounts received in return. It requires then that governments of those states explain to their citizens the frequently immeasurable value added arising from those transfers, which manifests itself, for example, as new markets.

It is believed that the current system of own resources is regressive, unclear and complicated, albeit stable. ${ }^{46}$ Hence the need of its simplification and higher autonomy.

Numerous recommendations and proposals of change have also been offered in a report prepared under the supervision of a French member of the European Parliament, A. Lamassoure. The report, entitled "Report on the future of the European Union's own resources"47 is extremely extensive, containing an exhaustive and thorough analysis of the problem.

It was proposed, among other things, that the future reformed system of EU's own resources should be based on the following principles:

- fully respected fiscal sovereignty of Member States,

- fiscal neutrality,

- maintenance of the till date existing size of the budget of the European Union,

\footnotetext{
${ }^{45}$ Ibidem, p. 5.

${ }^{46}$ Przeglad Budżetu UE. Raport z konsultacji społecznych, Warszawa 2008, p. 41.

${ }^{47}$ Report on the Future of the European Union's Own Resources (2006/2205(INI)), 13 March 2007, FINAL A6-0066/2007.
} 
- determination of clear principles of reform with regard revenues as well as budgetary expenditures;

- gradual implementation of change.

From the above mentioned principles, fiscal neutrality requires special attention as a feature which the new sources of budget revenues should possess. This feature may be identified as a situation in which budget revenues will not entail an increased total tax obligation of the citizens of Member States. A solution regarded as neutral is dividing one of the existing taxes into a national and a European part. Among the "candidates" for such division are: ${ }^{48}$ value added tax (VAT), corporation income tax (CIT), excise tax on fuel for motor engine vehicles used for transportation purposes, tax on transport and telecommunication services, excise tax on tobacco products, income tax, interest income tax, ECB seigniorage, environmental tax, financial transactions tax (FTT), tax on savings, and securities transactions tax. Another interesting proposal is basing budget revenues on contributions from those Member States which so far have been beneficiaries of the EU funds. This proposal arises from the belief that when income generating mechanisms (e.g. EU funds) are created, the benefits from those mechanisms must in a longer perspective contribute to the EU budget in the form of, for instance, taxes on those benefits. ${ }^{49}$

Another issue needing to be solved is efficiency of individual sources of the budget, or, in other words, their share in the budget which they can provide and ensure. It may be claimed that VAT, CIT, the new European tax, or the FTTs ${ }^{50}$ will be able to finance most of the EU budget needs. And as such, they have been given most attention in the debate, in which the positive and negative aspects of each of them have been identified.

The unquestionable advantages of the Union VAT include its: sufficiency, i.e. possibility of covering a large part of budget revenues, and its stability, i.e. a possibility of freeing the budget revenues from the dependence on direct payments from Member States. The construction of this solution would consist in the adoption of a EU VAT rate as

${ }^{48}$ Przegląd Budżetu UE..., p. 42-43.

${ }^{49}$ Ibidem. See also J. Haug et al., Europe for Growth. For Radical Change in Financing the EU, 2011, p. 30-57.

${ }^{50}$ See S. Schulmeister, M. Schratzenstaller, O. Picek, A General Financial Transaction Tax - Motives, Revenues, Feasibility and Effects, Wien 2008; J. Anthony et al., Financial Transaction Tax: Review and Assessment, CPB Discussion Paper 202, Amsterdam 2012; The EU Financial Transaction Tax Proposal: A Preliminary Evaluation, Central Bank of Ireland, April 2012. 
a proportion of the national (domestic) VAT rate paid by tax payers and calculated against the same tax base. Thus, the EU VAT would not create any additional burden on individuals (EU citizens) but be simply a part of the already existing national rate. However, the same tax would be divided into two parts and shown as two separate items in the invoice. This division has another aspect too, and is believed to tie the EU citizens to the idea of United Europe and their participation in the co-financing of its budget. ${ }^{51}$ Other positive sides of the proposed solution include its universality and immunity to the changes in the economy. The employment of the EU VAT for the purpose of financing the EU budget is of course not ideal or free from certain negatives features. One of the potential problems would be the necessity to end with the "zero" VAT rate currently applicable in certain Member States. Their resistance to do that is obvious. Another problem is the fact that currently there are no tax administration services within the EU that would be capable of handling the matters related to the new tax. Furthermore, a special mechanism would have to be developed (which in fact underlies the functioning of the VAT) through which the tax due could be lowered by tax calculated (and in consequence, where applicable, would allow tax recovery). ${ }^{52}$

Another proposed solution is a universal European tax that should be an acceptable neutral (not felt by tax payers as an additional financial burden tax, easy to collect and not generating additional administrative cost. ${ }^{53}$ However, due to the above restrictive requirements and some other reasons, implementation of this tax seems little realistic. As rightly noted by J. Le Cacheux, such tax would not receive political acceptance. Moreover, because of the existing differences in the wealth among European societies, one just (fair) rate of such tax or taxable basis for such tax applicable throughout Europe would be difficult to determine. ${ }^{54}$

From the very beginning, the discussion on the EU general budget reform has been going on alongside the work conducted on the Multiannual Financial Framework 2014-2020. Although that discussion contains

${ }^{51}$ E. Kawecka-Wyrzykowska, VAT as an EU Budget Resource - a Study Prepared at the Request of the Office for European Integration in Poland in the Framework of Consultations on the EU Budget Reform), Warszawa, January 2008, p. 45.

${ }^{52}$ Communication from the Commission - Reforming the budget, changing Europe - A public consultation paper in view of the 2008/2009 budget review, SEC(2007) 1188 final.

${ }^{53}$ J. Pietras, op. cit., p. 44 et seq.

${ }^{54}$ J. Le Cacheux, Funding the EU Budget with a Genuine Own Resource: The Case for a European Tax, "Notre Europe Studies" 2007, no. 57, p. 23-27. 
many aspects, its focus tends to be on the proposals of establishing a new catalogue of own resources and a proposal of a reform of the current financing system.

The proposed changes have been prompted by the fact that the current system is indeed complicated and unclear, and, as frequently indicated by commentators, lacking objectivity. An example of the latter flaw of the system is so-called UK rebate functioning interruptedly since 1984, which in consequence entailed financing exceptions allowed other Member States (Germany, the Netherlands, Austria and Sweden) in the form of "rebates for rebates". ${ }^{55}$ This has resulted in a complicated system of financing the general budget, constituting at the same time an argument for a change in the system of own resources. The change will not, however, come before 2020. The consensus reached in the course of negotiations on the MFF 2014-2020 and resulting from it Decision 2014/335 on the system of own resources of the European Union merely signalled the necessity of a change but did not substantiate it. Point 7 of the Preamble of the Decision makes a reference to the European Union budget but an analysis of its wording shows that it maintains the status $q u o$ with only certain minor corrections.

This does not mean that the proposal of the reform of the Union budget has been abandoned altogether. It has been supported by the European Parliament since the very beginning, and the EP has made a few proposals and initiatives, of which the most important one was appointment of a High-level Group on Own Resources, formally established on 25 February 2014 by the Presidents of the European Commission, the European Parliament and the Council of the European Union. The group is headed by former Italian Prime Minister and EU Commissioner Mario Monti, plus several members appointed by the European Parliament, the European Commission and the Council. Its main task is an overall analysis of the functioning of the system of the European Union budget, followed with a proposal of concrete solutions to be presented by the year 2016. The potential directions of change which the group is going to recommended are already known because in December 2014 the group presented its First Assessment Report ${ }^{56}$ in which

${ }^{55}$ I. Begg, Rethinking How to Pay for Europe, SIEPS, European Policy Analysis, 2010, p. $2-7$.

${ }^{56}$ High Level Group on Own Resources, Brussels 2014, http://ec.europa.eu/budget/ library/biblio/documents/multiannual_framework/HLGOR_1stassessment2014final_ en.pdf (accessed: 27 VII 2015). 
it summed up the already existing reform proposals and put forward new subjects for discussion together with the methodology in which such discussion should be conducted. The proposed methodology is extremely interesting as it is based on a handful of questions regarding three dimensions of the planned reform. They cover: ${ }^{57}$

1. the broader economic and political context of recent proposals,

2. legal, institutional and procedural aspects,

3. evaluation of the various candidates for new own resources in the light of point 1 and 2 .

Although each of the questions posed in the Report is important, it is tempting to identify already today the essential elements of the initiated debate. And so, as can be seen, a compromise will be worked on in order to find new "genuine" own resources, while limiting the dependence of the Union budget on own resources based on Gross National Income. As has been indicated in the Report, own resources are currently the main budget revenue category, constituting its "balancing" part. Although the GNI-based resource will be maintained, there is a wish to complement it with a new category/new categories of own resources can be noted. Among the most frequently mentioned candidates are, as indicated above, the financial transaction tax and the VAT (but in a new formula). ${ }^{58}$

The authors of the Report indicate that although the overall assessment of the current system is positive, there are four areas requiring change in the budgeting procedure: ${ }^{.9}$

1. the highly complicated multi-plane system of financing which requires numerous calculations

2. the dependence of the Union budget on contributions from Member States, which creates additional tensions in the nett payers - net beneficiaries relationships,

3. outstanding commitments (RAL, from the French 'reste à liquider') which are defined as the amount of appropriations committed that have not yet been paid ${ }^{60}$, and which arise from the existence of multiannual programmes and the dissociation between commitment and payment appropriations,

${ }^{57}$ Ibidem, p. 33-35.

${ }^{58}$ More on that in C. d'Oultremont, A. Mijs, Reforming the System of Financing the EE Budget, European Affairs Programme Working Paper, January 2013, p. 13-20.

${ }^{59}$ Ibidem, p. 13.

${ }^{60}$ Ibidem, p. 13-14. 
4. the extremely complicated procedure of decision-making in matters regarding own resources which subsequently needs several months to be formally accepted by relevant EU bodies, and which is also contingent upon constitutional requirements of Member States, and usually of little interest to respective public opinions.

\section{Conclusions}

The above issues will need to undergo changes otherwise the idea of the planned reform will be questionable. It is a good thing that the group intends to prepare the reform based on the assessment criteria formulated on the basis of a retrospective analysis and recommendations proposed by theoreticians and practitioners. The Report contains a table in which the main criteria are listed. They include features such as: efficiency, sufficiency and stability, transparency and simplicity, democratic accountability and budgetary discipline, as well as promotion of the European added value (but constraining the narrow self-interest), the subsidiarity principle and fiscal sovereignty of member states, or limitation of political transaction costs. ${ }^{61}$

Another extremely important issue raised in the Report is reflected in the following questions: Is there a common perception of what should be the essential criteria on which a reform of EU financing should be based? Can these criteria be defined objectively? ${ }^{62}$ These questions constitute the foundations underlying the whole debate. Although and obviously the construction of the European Union must be based on a political compromise worked out by its Member States, in certain situations it may be worthwhile to look more deeply and refer to those values which governed the founding fathers. This is particularly important today, when the fate of the united Europe is at stake. Although the reform of the EU budget is but one of the elements of the intricately constructed jigsaw puzzle, its role cannot be underestimated. The nominal EU budget is approximately EUR 145 milliard (Amer.: billion) which accounts for less (2015) than 1\% of the GDP of all its Member States. A good, wise spending of that amount may not only contribute to improvement financial condition of the Europeans, but may also bring about changes in their mentality, strengthen the feeling of European

\footnotetext{
${ }^{61}$ Ibidem, p. 26.

${ }^{62}$ Ibidem, p. 35.
} 
identity based on common and shared values. But are there such values? Do they exist? If the answer is yes, which of those should be referred to in the budget reform currently under preparation? Can private entities, such as, say, banks, participate in the process, realising at the same time the idea of "business and human rights"?

\section{REFORMA BUDŻETU UNII EUROPEJSKIEJ JAKO PROCES WZMACNIANIA EUROPEJSKIEJ TOŻSAMOŚCI. CZY EUROPEJCZYCY SĄ NA NIĄ GOTOWI?}

\section{Streszczenie}

Stan finansów Unii Europejskiej stanowi od wielu lat przedmiot ożywionej debaty publicznej. Dotyczy to kilku elementów, z których obecnie za najważniejsze należy uznać: kryzys finansowy, sytuację w strefie euro, kryzys migracyjny, a w ostatnim czasie wyzwania, przed jakimi stanie Unia Europejska w sytuacji opuszczenia jej przez Wielką Brytanię. Wszystkie wymienione elementy to jedynie część aktualnych problemów mogących zadecydować o przyszłości Zjednoczonej Europy - Europy, której proces jednoczenia, mimo niewątpliwych błędów popełnionych po drodze, uznać można za zakończony sukcesem. Wydaje się wszakże, iż w pewnym momencie ideologia jednoczenia przysłoniła istotę budowania efektywnych struktur europejskich. Zaczęły bowiem dominować interesy indywidualne poszczególnych państw, a wartości przyświecające ojcom założycielom Unii Europejskiej zostały zmarginalizowane. Dowodem na to jest sytuacja budżetu ogólnego Unii Europejskiej, który w swej istocie stanowić miał instrument realizacji idei i wartości unijnych. Niestety, poprzez wprowadzanie kolejnych wyjątków od zasad nim rządzących, wyrażających się między innymi w uprzywilejowaniu poszczególnych państw, doprowadzono do tego, że w dyskusji na jego temat zaczęła dominować retoryka zamykająca się w zdaniu: „kto dał więcej, a kto mniej”. W związku z tym zatracono sens realizacji zasady solidarności, tj. faktycznego wyrównywania szans pomiędzy państwami czy też regionami, a także wartości dodanej tworzonej przez poszczególne wydatki budżetowe. Należy stwierdzić, że wzrost nastrojów antyeuropejskich w połączeniu z powolnym odchodzeniem od fundamentalnych wartości, na których historycznie budowana była Europa, godzi w kształtowanie tożsamości europejskiej. Nie wszystko jednak stracone. Konieczne jest wprowadzenie zmian, które przywrócą Europie jej europejskość i pozwolą utrzymać pozycję we współczesnym świecie. Z całą pewnością jednym z instrumentów prowadzących do tego celu powinien być budżet ogólny Unii Europejskiej, którego struktura oraz mechanizmy funkcjonowania, podobnie jak instytucje unijne, muszą być wszakże poddane reformie.

Słowa kluczowe: budżet Unii Europejskiej - Unia Europejska - tożsamość europejska - wartość dodana - reformy 